\title{
A new point mutation in the luteinising hormone receptor gene in familial and sporadic male limited precocious puberty: genotype does not always correlate with phenotype
}

\author{
B A J Evans, D J Bowen, P J Smith, P E Clayton, J W Gregory
}

\begin{abstract}
Genomic DNA from two families with male limited precocious puberty was examined for mutations of the $L H$ receptor gene. In family 1 , several members of the pedigree have FMPP, whereas in family 2 there is only one affected subject. A point mutation $(T \rightarrow C$ at nucleotide 1192) resulting in substitution of threonine for methionine 398 in the second transmembrane domain of the LH receptor protein was found in both families. In addition, one member of family 1 has the mutation, but no evidence of precocious puberty. All obligate carriers within this family were shown to have the mutation, and it was not detected in 94 chromosomes from unaffected and unrelated white subjects. In family 2, the index case was the only one to have the mutation. A previously unreported neutral dimorphism $(C \rightarrow T$ at nucleotide 1065) is also described. ( $f$ Med Genet 1996;33:143-147)
\end{abstract}

Key words: new LH receptor mutation.

Department of Child Health, University of Wales College of Medicine,

Heath Park,

Cardiff CF4 4XN, UK

B A J Evans

J W Gregory

Department of Haematology, University of Wales College of Medicine, Heath Park, Cardiff CF4 4XN, UK D J Bowen

The Royal Victoria Infirmary,

Newcastle upon Tyne NE1 4LP, UK

$P$ J Smith

Royal Manchester Children's Hospital, Pendlebury, Manchester M27 4HA UK

P E Clayton

Correspondence to: Dr Evans.

Received 3 June 1995 Revised version accepted for publication

23 October 1995 turnal pulsatile gonadotrophin secretion though a limited gonadotrophin response to the administration of intravenous gonadotrophin releasing hormone may occur. ${ }^{12}$ The precise causative mechanism is unknown, but the observation of mutations in the luteinising hormone (LH) receptor gene support the hypothesis that constitutive activation of the $\mathrm{LH}$ receptor is the pathogenetic mechanism responsible. ${ }^{3-7}$

The LH receptor is a member of the family of glycoprotein hormone receptors which are involved in hormone dependent signal transduction through coupling with guanine nucleotide binding regulatory proteins (G proteins). ${ }^{8}$ Molecular cloning has shown an $\mathrm{LH}$ receptor protein that consists of seven transmembrane domains, four cytoplasmic domains consisting of three cytoplasmic loops and the C-terminus, and four extracellular domains
Ligand binding causes a change in the conformation of this family of receptors, which in turn facilitates $G$ protein binding. This is followed by the exchange of GDP for GTP and the dissociation of the $\alpha$ subunit of the $G$ protein which subsequently activates adenyl cyclase.

Several recent reports hypothesise that FMPP might be the result of a mutant $\mathrm{LH}$ that is activated in the presence of little or no agonist. ${ }^{3-7112}$ The first paper ${ }^{3}$ described a single base change that results in substitution of glycine for aspartate at position 578 in the sixth transmembrane helix of the $\mathrm{LH}$ receptor in affected subjects from eight different families. Since then, however, other workers ${ }^{4-71112}$ have reported six different point mutations of the $\mathrm{LH}$ receptor gene in familial and sporadic cases of male limited precocious puberty. The region containing these activating mutations includes residues 541-581, and spans part of the fifth transmembrane helix, the intervening third cytoplasmic loop, and the majority of the sixth transmembrane helix. No mutations have been reported outside this region. Laue et $a l^{7}$ concluded that the region spanning nucleotides 1624-1741 of exon 11 of the LH receptor gene is a hotspot for heterogeneous mutations that constitutively activate the $\mathrm{LH}$ receptor and cause FMPP.

We therefore searched for mutations in a large portion of the $\mathrm{LH}$ receptor gene in two families in whom members had male limited precocious puberty in an attempt to elucidate further the link between mutations of the $\mathrm{LH}$ receptor gene and this condition. consisting of three loops and the N-terminus. ${ }^{910}$

\section{Patients}

FAMILY 1

The index case (II 2 , fig 1B) presented at the age of 7 years with precocious puberty (height velocity $9.6 \mathrm{~cm} /$ year, testes 5 and $6 \mathrm{ml}$, genitalia stage 3 , pubic hair stage 2). ${ }^{13} \mathrm{He}$ was troubled by an undiagnosed blistering and scarring skin condition but had no other abnormal past medical history. Twenty-four hour serum profiling showed no evidence of spontaneous gonadotrophin pulsatility (all LH and FSH concentrations less than $0.5 \mathrm{IU} / \mathrm{l}$ ) and the response to LHRH stimulation was negligible. Serum testosterone concentrations increased from $1.8 \mathrm{nmol} / 1$ to $18.8 \mathrm{nmol} / 1$ following human chorionic gonadotrophin stimulation. Magnetic resonance imaging of the brain was nor- 
A

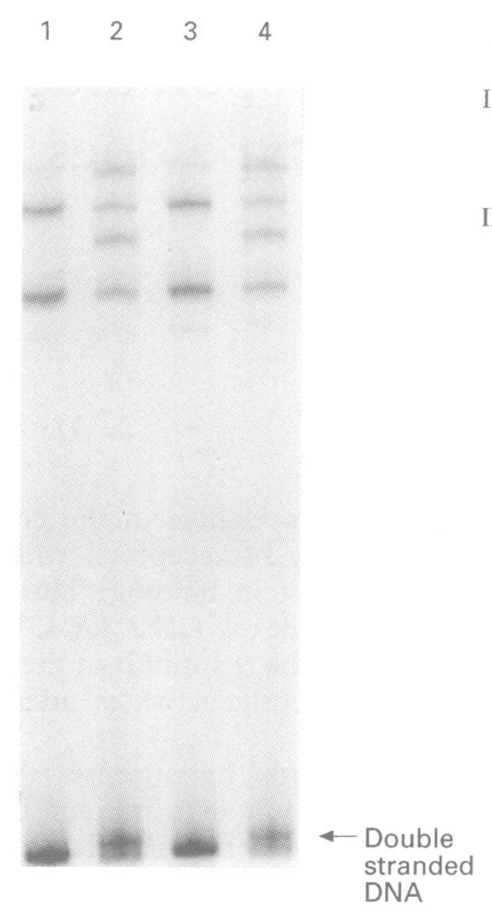

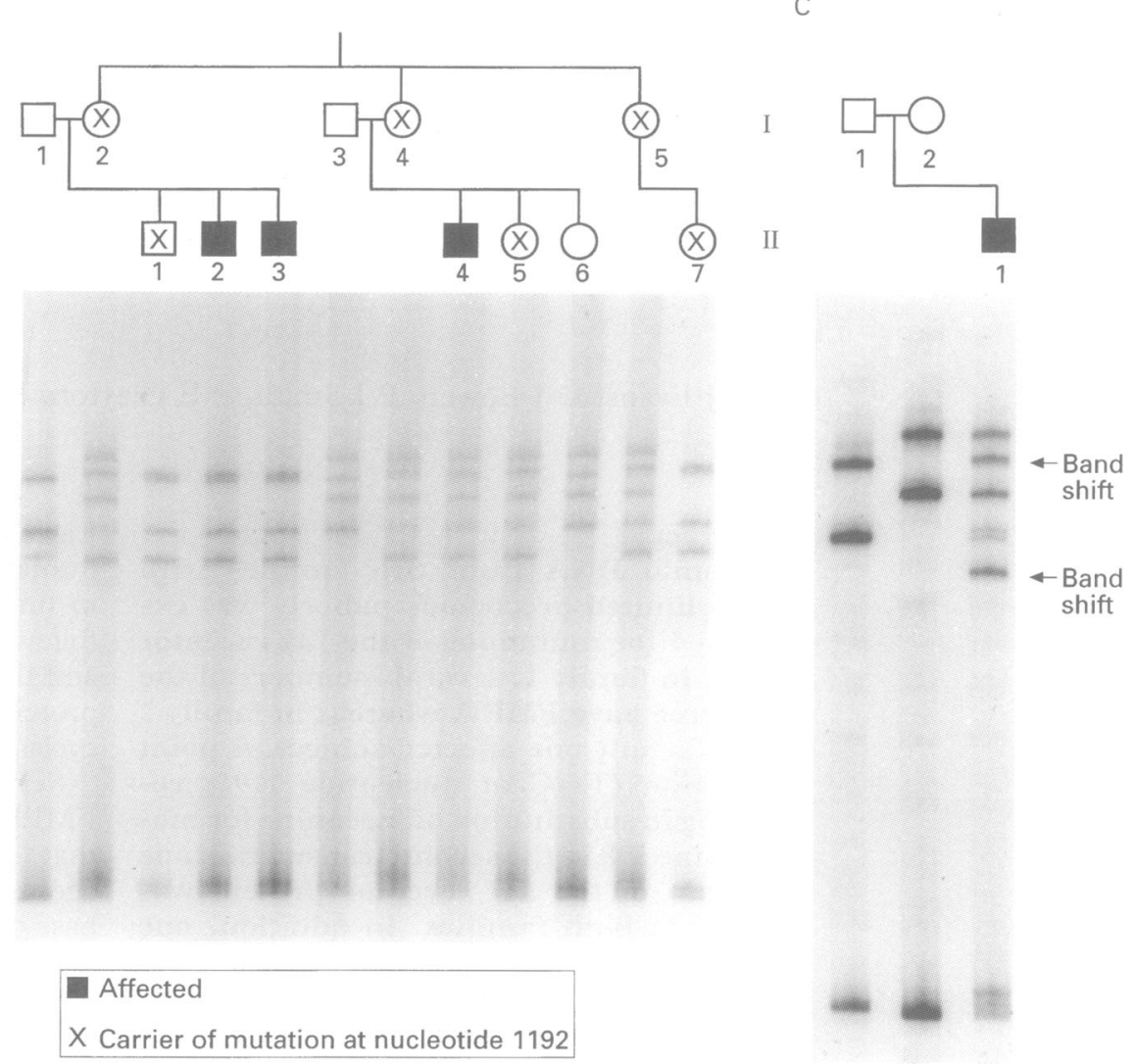

Figure 1 SSCP analysis of part (amplified by primer pair 1) of the LH receptor gene from (A) four normal subjects, (B) members of family 1 , and (C) members of family 2. The different patterns in $(A)$ are the result of a silent dimorphism at nucleotide 1065. This difference is also shown in the patterns obtained with double stranded DNA. The other patterns in $(B)$ and $(C)$ are the result of a point mutation at nucleotide 1192. Both of these changes are also reflected in the patterns obtained with double stranded DNA.

mal. He experienced a marked increase in testicular volume over the next six months and was then treated with cyproterone acetate. His older brother (II-1) is aged 12 years and has no clinical signs of spontaneous puberty. His younger brother (II.3) has albinism and at the age of $5 \cdot 5$ years has early pubic hair and genital development with evidence of testicular enlargement in keeping with precocious puberty. The parents are said to have entered puberty at the normal time but a cousin (II.4) is also reported to have experienced precocious puberty.

FAMILY 2

The index case in this family (fig $1 \mathrm{C}$ ) developed pubic hair at the age of 2 years. Over the next two years, this increased in amount and was associated with penile enlargement, acne, increased height velocity $(13.6 \mathrm{~cm} /$ year $)$, and aggressive behaviour. His past medical history was otherwise unremarkable and there was no family history of precocious puberty. At the age of 4.6 years, he had stage 3 pubic hair and genitalia with $7 \mathrm{ml}$ testes bilaterally. Apart from a café au lait patch on the costal margin, there were no other abnormal physical findings. The serum gonadotrophin response to LHRH was negligible (maximum LH $0.8 \mathrm{IU} / 1$ and $\mathrm{FSH}$ $1 \cdot 4 \mathrm{IU} / \mathrm{l})$ and adrenal and cranial CT scans were normal. $\mathrm{He}$ was therefore treated with cyproterone acetate.

\section{Methods}

PCR-SSCP ANALYSIS OF THE LH RECEPTOR GENE Genomic DNA was isolated by standard methods from peripheral blood obtained from members of the two families described above and depicted in fig $1 \mathrm{~B}$ and $\mathrm{C}$. The $\mathrm{LH}$ receptor gene (nucleotide 951 to $2133^{\circ}$ ) was screened for mutations using PCR-single strand conformation polymorphism (SSCP) analysis. ${ }^{1415}$ Three pairs of oligonucleotide primers were used to amplify sequences coding for the seven transmembrane domains, as well as the three intracellular and three extracellular loops of the LH protein.

The following primers were used: 1 a $5^{\prime}$-TTCTTCCATGCTTGCTGAGAGTG-3'; 1b 5'GGTGAGGGTGTAGACAGAAAGTTC-3'; 2a 5'-CACTGCTGGCTTTTTCACTGTATT-3'; 2b 5'-TGAAGGCAGCTGAGATGGCAAAAA-3'; 3a 5'-TTCACCGATTTCACCTGCATGGCA-3'; 3b 5'-GAGGTCTCTTGCCTAATGTACCT-3'.

Amplification was performed in a $10 \mu \mathrm{l}$ reaction mix containing $1 \mu \mathrm{g}$ of genomic DNA, $100 \mu \mathrm{mol} / 1$ each $\mathrm{dNTP}, 2 \mu \mathrm{mol} / 1$ each primer, $0.25 \mu \mathrm{Ci}\left(\alpha^{32} \mathrm{P}\right)$-dATP, 0.5 units $\mathrm{Taq}$ polymerase (Promega), and $1 \mu \mathrm{l} 10 \times$ PCR buffer $(10 \mathrm{mmol} / 1 \mathrm{Tris}-\mathrm{HCl} \mathrm{pH} 9 \cdot 0,0 \cdot 1 \%$ Triton X$100,50 \mathrm{mmol} / 1 \mathrm{KCl}$, and $25 \mathrm{mmol} / 1 \mathrm{MgCl}_{2}$ ). Reactions were denatured at $95^{\circ} \mathrm{C}$ for five minutes and subjected to 30 cycles of $95^{\circ} \mathrm{C}$ for 60 seconds, $57^{\circ} \mathrm{C}$ for 60 seconds, and $72^{\circ} \mathrm{C}$ for 30 seconds. Denatured amplified fragments 
were analysed for single strand conformation polymorphisms on non-denaturing polyacrylamide gels under two sets of conditions. Gels containing $6 \%$ acrylamide (acrylamide:bisacrylamide $37 \cdot 5: 1)$ and $1 \times \mathrm{TBE}(90 \mathrm{mmol} / 1$ Tris $\mathrm{pH} 8.3,90 \mathrm{mmol} / 1$ boric acid, $2.5 \mathrm{mmol} / 1$ EDTA) were run at $5^{\circ} \mathrm{C}$, and those containing $10 \%$ glycerol, $6 \%$ acrylamide, and $1 \times \mathrm{TBE}$ were run at $22^{\circ} \mathrm{C}$. All gels were electrophoresed at 25 watts, fixed in $10 \%$ acetic acid, and dried overnight before autoradiography. The presence of a mutation was indicated by a shift in the mobility of denatured PCR segments when compared to normal DNA. In some cases SSCP gels were not fixed or dried but covered with saran wrap and subjected to autoradiography. Areas of the gel corresponding to normal or mutant bands were then cut out of the gel, left in TE $(10 \mathrm{mmol} / 1$ Tris $\mathrm{pH} 7 \cdot 4$, $1 \mathrm{mmol} / \mathrm{l}$ EDTA) buffer overnight, and spun through glass wool to remove the acrylamide gel. The eluate was then subjected to amplification by PCR techniques as described previously and prepared for sequencing as described below.

DNA SEQUENCING OF PCR PRODUCTS

Scaled up versions of the PCR reactions described above were carried out in a total volume of $100 \mu \mathrm{l}$ and without $\left(\alpha^{32} \mathrm{P}\right)$ dATP. Duplicate reactions were pooled and run on a $0.8 \%$ low melting point agarose gel in $1 \times \mathrm{TAE}(4 \mathrm{mmol} / 1$ Tris $\mathrm{pH} 7 \cdot 8,500 \mu \mathrm{mol} / 1$ sodium acetate, 100 $\mu \mathrm{mol} / 1 \mathrm{EDTA})$. The appropriate bands were excised and the DNA purified using the Magic PCR Preps DNA Purification kit (Promega). The eluate was used directly for sequencing reactions with a Dyedeoxy Terminator Cycle Sequencing Kit and a Model 373A DNA Sequencing System (Applied Biosystems). In some cases the eluate was used for a $100 \mu \mathrm{l}$ asymmetrical PCR reaction with a 5:1 ratio of primers. The product was again purified using the Magic PCR Preps described above and the products sequenced with the limiting or an internal (5'-TTCTAGCCATCATGG-3') primer using Sequenase V2.0 (Amersham Life Sciences). Sequencing reactions were modified from those recommended by the manufacturer by the omission of the labelling reaction; Sequenase, dideoxy dNTPs, and $\left(\alpha^{32} P\right) d C T P$ in reaction buffer were directly added to asymmetrical PCR templates.

\section{DIGESTION OF PCR PRODUCTS WITH NlaIII OR}

$B b s \mathrm{I}$

Studies of specific mutations in the fragment generated with primers $1 \mathrm{a}$ and $1 \mathrm{~b}$ were performed by restriction enzyme digestion analysis of PCR products. Amplification was carried out as previously described and $10 \mu \mathrm{l}$ of the reaction mixture digested with $P m I$ or $B b s I I$ (New England Biolabs) as specified by the manufacturers. PmlI and BbsI restriction fragments were separated on agarose gels (3\% Nusieve $^{\mathrm{TM}}$ 3:1 agarose (Flowgen Instruments) for PmlI, and 4\% MetaPhor ${ }^{\mathrm{TM}}$ agarose (Flowgen Instruments) for $B b s \mathrm{I}$ ), and stained with ethidium bromide to allow visualisation of the DNA. The PCR reactions carried out before these restriction enzyme digests were new reactions using stock DNA solutions, in case the other results obtained during the course of the study were the result of PCR generated artefacts.

\section{Results}

PCR-SSCP ANALYSIS

PCR-SSCP analysis of DNA fragments amplified with the three pairs of primers described in the methods section showed band shifts with primer pair 1 only. Initial studies showed two different patterns within the normal population (fig 1A) with a third pattern present in nine members of family 1 and one member of family 2 (fig $1 \mathrm{~B}, \mathrm{C}$ ).

\section{SEQUENCING OF PCR PRODUCTS}

Manual and automated sequencing showed two point mutations in the region amplified by primer pair 1 when the sequences obtained were compared to the published sequences ${ }^{9}:$ (1)

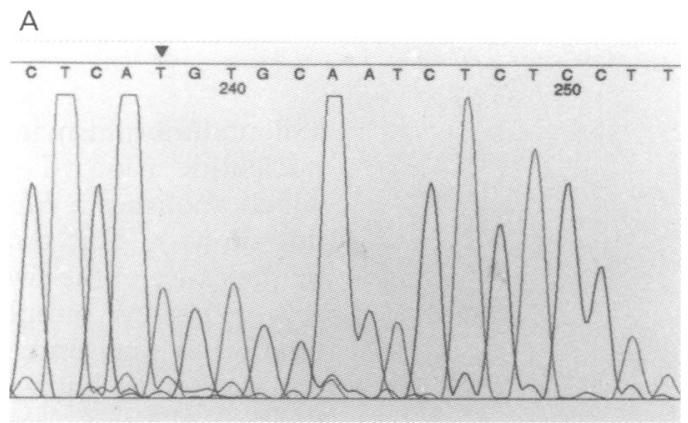

B

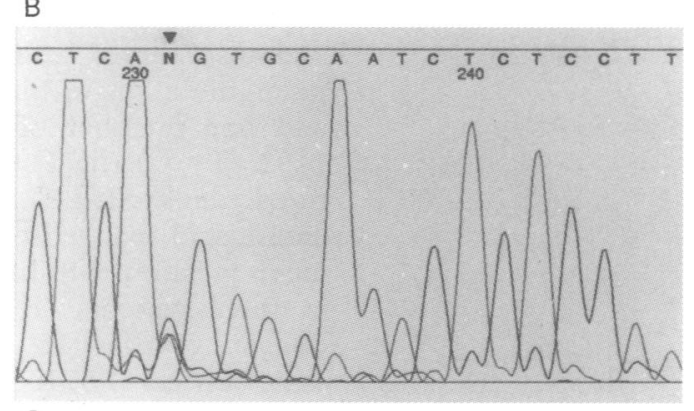

C

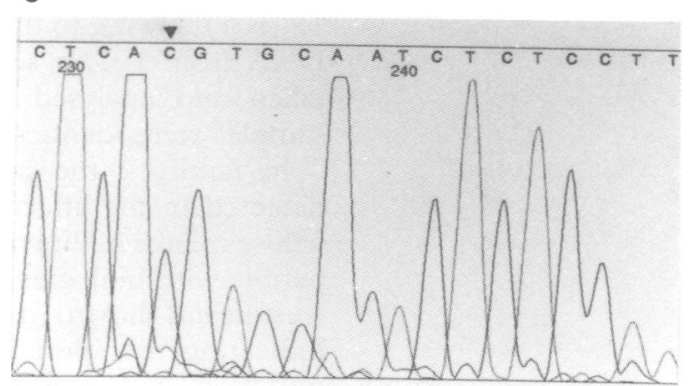

Nucleotide 1192

Figure 2 Sequence of part of PCR product (primer pair 1) from (A) a normal control, (B) a heterozygous mutant, and $(C)$ band containing mutation (family 2 II-1) cut from SSCP gel. 


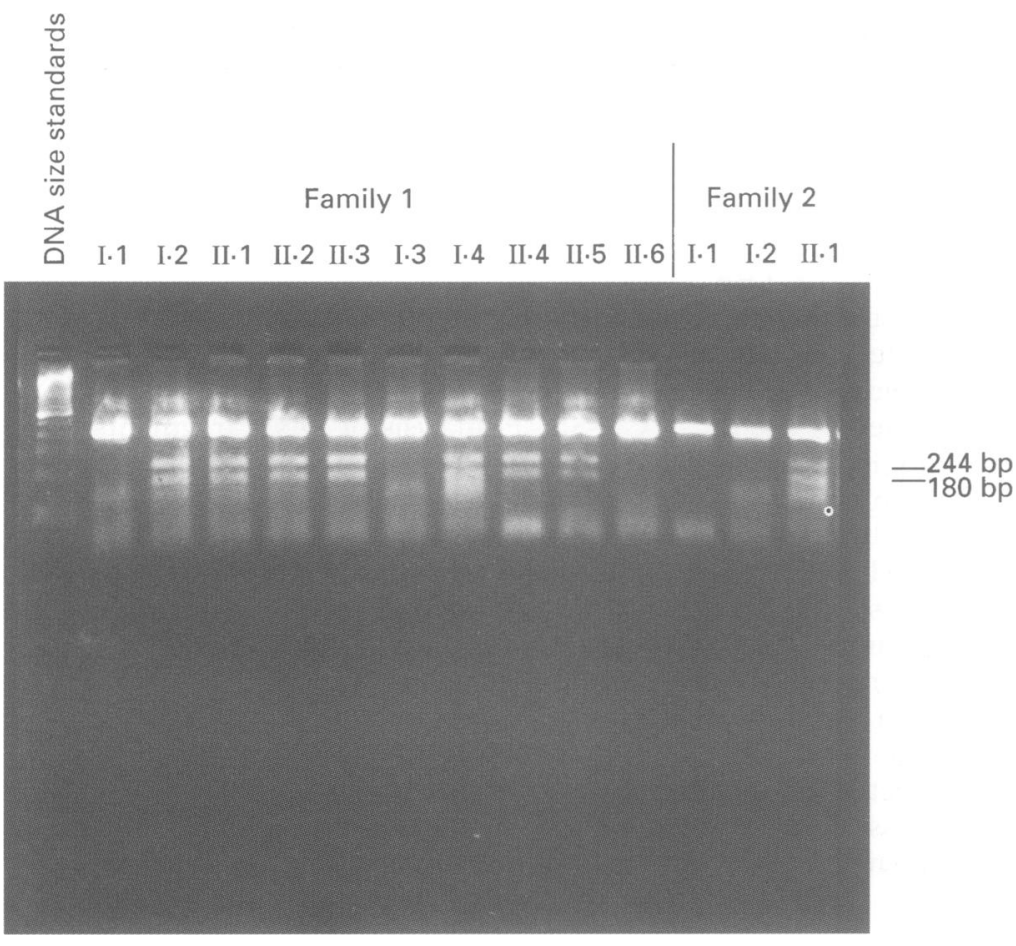

Figure 3 Digestion of PCR products (primer pair 1) with PmlI showing the presence of two bands (244 and $180 \mathrm{bp}$ ), owing to the introduction of a new cutting site, in eight subjects. These two bands were also present when $I \cdot 5$ and II.7 from family 1 were analysed (results not shown).
DNA which has mutated at nucleotide 1192 . The mutation was not detected in a study of unaffected and unrelated white subjects (94 chromosomes).

Owing to the fact that the region spanning nucleotides $1624-1741$ of the LH receptor gene has been reported as a hotspot for mutations that constitutively activate the receptor, we sequenced the region amplified by primer pair 2 (nucleotide 1320-1783) in DNA from two affected subjects (II.2 from family 1 and II 2 from family 2). No mutations were detected.

\section{Discussion}

In the current study, we examined the LH receptor gene in two families with precocious puberty. In one family there are three affected members, while in the other, because of the absence of family history of disease, there is apparently sporadic FMPP. In both, we describe a new point mutation (nucleotide 1192) in the LH receptor DNA, which results in the substitution of methionine (non-polar) 398 with threonine (polar) in the $\mathrm{LH}$ receptor protein. This amino acid substitution is in the second transmembrane domain of the receptor protein, and it is the first time that a mutation has been reported outside the hotspot region (nucleotides 1624-1741) described in the introduction. $^{7}$

Three male sibs (II 1 , II $\cdot 2$, and II 3 ) from family 1 have been shown to have this methionine 398 to threonine mutation. II $\cdot 2$ was the index case diagnosed as having FMPP at the age of 7 years. II. 3 is currently aged 5 years and is now showing early clinical signs of precocious puberty. II $\cdot 1$, however, is now aged 12 years and remains prepubertal. All obligate carriers within the family were shown to have the mutation. Since the mutation was not detected in 94 chromosomes from unaffected and unrelated white subjects and was found in a sporadic case of male precocious puberty, it is probably the cause of FMPP in these two families. Why II $\cdot 1$ is not affected, however, is not understood, and may indicate that other factors influence the clinical presentation of FMPP. It is also interesting to note that the affected subject in family 2 was diagnosed at a much earlier age (4 years) than those in family 1 ( 7 and $5 \cdot 5$ years). These differences in phenotypic expression may be explained by differences in basal LH receptor activity.

The release of conformational constraints following ligand binding is essential in the activation of $G$ protein coupled receptors. Six human diseases are now thought to be caused by mutations which result in constitutive activation of $G$ protein coupled receptors: retinitis pigmentosa, ${ }^{16}$ hyperfunctioning thyroid adenomas, ${ }^{17}$ autosomal dominant toxic thyroid hyperplasia, ${ }^{18}$ autosomal dominant hypocalcaemia, ${ }^{19}$ congenital night blindness, ${ }^{20}$ and FMPP. ${ }^{4-7}$ Most of these mutations are towards the $3^{\prime}$ end of the receptor in regions which code for the third intracellular loop and the sixth and seventh transmembrane domains of the relevant binding protein. The human rhod-

family $2(\mathrm{II} \cdot 1)$ would have a normal allele from his mother and a normal allele from his father, as well as the mutant DNA. From the SSCP results this is not the case, and it is the father's 
opsin gene mutation, which results in the substitution of glycine 90 with asparagine and apparently accounts for congenital night blindness, however, is on the second transmembrane helix. ${ }^{20}$ It is also worth noting that point mutations in the second transmembrane domain and first cytoplasmic loop of the receptor for murine melanocyte stimulating hormone, which lead to darkened coat colour, have been shown to cause constitutive activation of, or hyper-responsiveness of, that receptor. ${ }^{21}$

In summary, we have identified a previously unreported point mutation of the $\mathrm{LH}$ receptor gene in two families with FMPP, one with the inherited form and the other a sporadic occurrence of the condition. Within the family with the inherited form of FMPP, however, one subject has the mutation but is currently prepubertal at the age of 12 . This variable phenotype within one family suggests that genetic counselling should be carried out with caution in this condition. A previously unreported neutral dimorphism is also described. Further work in the form of expression studies should now be carried out to confirm constitutive activation of the methionine 398 to threonine mutation. This, in turn, would lead to the study of the three dimensional conformation of the receptor domains involved in ligand binding and $G$ protein activation.

1 Rosenthal SM, Grumbach MM, Kaplan SL. Gonadotropinindependent familial sexual precocity with premature independent familial sexual precocity with premature sis): effects of a potent luteinizing hormone releasing sis): effects of a potent luteinizing hormone releasing
factor agonist and medroxyprogesterone acetate therapy factor agonist and medroxyprogesterone acetate thera
in four cases. $f$ Clin Endocrinol Metab 1983;57:571-9.

2 Wierman ME, Beardsworth DE, Mansfield J, et al. Puberty without gonadotrophins: a unique mechanism of sexual development. $N$ Engl F Med 1985;312:65-72.

3 Shenker A, Laue L, Kosugi S, et al. A constitutively activating mutation of the luteinizing hormone receptor in familial male precocious puberty. Nature 1993;365:652-4

4 Kremer H, Mariman E, Otten BJ, et al. Cosegregation of missense mutations of the luteinizing hormone recepto gene with familial male-limited precocious puberty. Mol Genet 1993;2:1779-83.
5 Yano K, Hidaka A, Saji M, et al. A sporadic case of malelimited precocious puberty has the same constitutively activating point mutation in luteinizing hormone/choriogonadotropin receptor gene as familial cases. 7 Clin Endocrinol Metab 1994;79:1818-23.

6 Yano K, Saji M, Hidaki A, et al. A new constitutively activating point mutation in the luteinizing hormone/choriogonadotropin receptor gene in cases of male-limited precocious puberty. F Clin Endocrinol Metab 1995;80:11628.

7 Laue L, Chan WY, Hseuh AJW, et al. Genetic heterogeneity of constitutively activating mutations of the human leuteinizing hormone receptor in familial male-limited precocious puberty Pat Acad Sci USA 1995;92: 1906-10.

8 Savarese TM, Fraser CM. In vitro mutagenesis and the search for structure-function relationships among $G$ prosearch for structure-function relationships among

9 Minegish T, Nakamura K, Takakura Y, et al. Cloning and sequencing of human LH/hCG receptor cDNA. Biochem Biophys Res Commun 1990;172:1049-54.

10 Koo YB, Ji I, Slaughter G, Tae HJ. Structure of the luteinizing hormone receptor gene and multiple exons of the coding sequence. Endocrinology 1991;128:2297-308.

11 Shenker A, Van Dop C, Geffner ME, et al. Heterogeneity of luteinizing hormone receptor (LHR) gene mutations in familial male precocious puberty. Pediatr Res 1994;35: A106.

12 Boepple PA, Crowley WF Jr, Albanese C, Jameson JL Activating mutations of the $\mathrm{LH}$ receptor in sporadic male gonadotropin-independent precocious puberty. Proceedings of the 76th Annual Meeting of the Endocrine Society 1994:494.

13 Tanner JM. Growth at adolescence. 2nd ed. Oxford: Blackwell Scientific Publications, 1962.

14 Orita M, Suzuki Y, Sekiya T, Hayashi K. Rapid and sensitive detection of point mutations and DNA polymorphisms using the polymerase chain reaction. Genomics $1989 ; 5$ 874-9.

15 Batch J, Williams D, Davies $\mathrm{H}$, et al. Androgen receptor gene mutations identified by SSCP in fourteen subjects with androgen insensitivity syndrome. Hum Mol Genet 1992;1:497-503.

16 Robinson PR, Cohen GB, Zhukovsky EA, Oprian DD. Constitutively active mutants of rhodopsin. Neuron 1992; 9:719-25.

17 Parma J, Duprez L, Van Sande J, et al. Somatic mutations in the thyrotropin receptor gene cause hyperfunctioning in the thyrotropin receptor gene cause hyp

18 Duprez L, Parma J, Van Dande J, et al. Germline mutations in the thyrotropin receptor gene cause non-autoimmune autosomal dominant hyperthyroidism. Nature Genetics 1994;7:396-401.

19 Pollak M, Brown EM, Estep HL, et al. Autosomal dominant hypocalcaemia caused by a $\mathrm{Ca}^{2+}$-sensing receptor gene mutation. Nature Genet 1994;8:303-7.

20 Sieving PA, Richards JE, Naarendorp F, et al. Dark-light: model for nightblindness from the human rhodopsin Gly90 $\rightarrow$ Asp mutation. Proc Natl Acad Sci USA 1995;92: $880-4$.

21 Robbins LS, Nadeau JH, Johnson KR, et al. Pigmentation phenotypes of variant extension locus alleles result from point mutations that alter $\mathrm{MSH}$ receptor function. Cell 1993;72:827-34. 